\title{
Teacher Opinions about Children's Awareness of Zero- Waste and Recycling in the Pre-School Education Years
}

\author{
Ayhan BULUT' 1 \\ Bayburt University, Bayburt, TURKEY
}

1 Dr. Bayburt University, Department of Preschool Education, Bayburt, Turkey. ayhanbulut [at] bayburt.edu.tr, ORCID: 0000-0001-6482-8032

\begin{abstract}
The aim of this study is to encourage the development of pre-school teachers by raising their awareness about zerowaste and recycling activities. The need for this research is linked to the lack of prominence about the concept of zerowaste in pre-school programs in Turkey, and also the limited inclusion of opportunities for pre-school students to learn about recycling strategies. This research uses a qualitative design and adopts a case-study approach. The study group was purposefully sampled using criterion-sampling. Interviews were conducted with forty pre-school education teachers who volunteered to support the research, had at least five years experience, and had received training about zero-waste and recycling activities. The interviews with pre-school education teachers were conducted once and took approximately fifty minutes. Content analysis and descriptive analysis approaches were employed. The research findings were based on each interview question, and tables were created under five headings. Research findings indicate that most of the pre-school education teachers stated the children's awareness about zero-waste and recycling was insufficient during the pre-school education years. Teachers have stated that awareness about zero-waste and recycling can be enriched through the inclusion of specific content and the use of visual materials in pre-school education programs. Additionally, pre-school education teachers emphasized that using an educational game will make the learning process about zero-waste and recycling strategies more enjoyable and will also be the most suitable method in terms of the children's age and levels of development. On the other hand, teachers have stated that in order to raise children's awareness about zero-waste and recycling, there should be further studies conducted about how such awareness will contribute to the social and emotional development of children as well as studies about how children can learn-by-doing.
\end{abstract}

\section{Keywords}

Recycling, Zero-Waste, Pre-School

To cite this article: Bulut, A. (2020). Teacher Opinions about Children's Awareness of Zero-Waste and Recycling in the PreSchool Education Years. Review of International Geographical Education (RIGEO), 10(3), 351-372. Retrieved from http://www.rigeo.org/vol10no3/Number3Summer/RIGEO-V10-N3-5.pdf. . doi: 10.33403rigeo.689426 
A rapid increase in world population has increased the demand and need for natural resources to sustain global life. In so doing, this has emphasized the importance of effective and efficient use of natural resources as the lifeblood of a well-functioning economy. Unfortunately, the relentless and unconscionable use of natural resources throughout the world has brought the supply of some natural resources to the point of exhaustion. Therefore, the world has become an increasingly unequal place where inadequate access to economic resources often prevails for the population of underdeveloped and developing countries. Although various types of research, conferences and meetings about poverty and hunger have been conducted across the world, it is predicted that most of the people who suffer from hunger and poverty will be more deeply affected by, and also more frequently encounter the problem of unequal access to natural resources (Cooper, 2005). Lately, the shrinkage or depletion of renewable and non-renewable energy sources in the world has expanded the scope of the problem.

While energy resources are classified according to their use as renewable and non-renewable energy, when energy resources are categorized according to their renewability they are identified as primary and secondary energy sources (see Table 1). Non-renewable energy sources are supposed to be consumed in a short time, and they are separated into fossil sources and nuclear sources. Renewable energy sources are considered to be inexhaustible and able to renew themselves, thus being able to endure long into the future. Energy sources are presented in Table 1 below (Koç, Kaya, 2015).

Table 1

Renewable and Non-Renewable Energy Sourcesv (Kaya, Şenel and Koç, 2018)

\begin{tabular}{ll}
\hline & Energy Sources \\
\hline According to Their Use & According to Their Renewability \\
\hline A) Non-Renewable (Depletable) & A) Primary \\
\hline Fossil Sources & Coal \\
Coal & Oil \\
Oil & Gas \\
Gas & Nuclear \\
Nuclear Sources & Bio-mass \\
Uranium & Hydrolic \\
Thorium & Solar \\
& Wind \\
& Wave, Tidal \\
\hline B) Renewable & B) Secondary \\
Hydraulic & Electricity- Gasoline \\
Solar & Diesel Fuel- Diesel Oil \\
Bio-mass & Coke, Petrocoke \\
Wind & Liquified Petroleum Gas (LPG) \\
Geothermal & \\
Wave, Tidal & \\
Hydrogen & \\
\hline
\end{tabular}

Primary energy sources are oil, coal, natural gas, nuclear, hydraulic, biomass, wave-tide, solar, and wind. The energy acquired by the conversion of primary energy is also termed secondary energy. As can be observed in Table 1, these are electricity, gasoline, diesel oil, diesel, coke, secondary coal, petrocoke, air gas, liquified petroleum gas (LPG) (Şenel, 2012). 
The rapid change in industrial development and use of technology together with the fact that urban life has become more desirable all over the world have meant that consumption habits have changed and this has led to the emergence of much more waste material occurring today compared to previous decades. Waste material, regardless of its origin (domestic, commercial, or industrial) means that once the natural resource has been used, and the waste material has been generated, the resource loses both its usefulness and financial value. "Reuse," "reduce," and "recycle" activities, have gained weight in their use because the purpose of such activities are to prevent environmental pollution and encourage the effective use of resources, (Guide and Van Wassenhove, 2009). Scientists admit that recycling is one of the most efficient ways to decrease the consumption of natural resources and prevent environmental problems (Gadiraju, 2016; Poskus, 2015). Although more attention should be given to universal issues, such as creating awareness about zero-waste and recycling, the nature and rate of consumption of energy resources, the nature and rate of global warming, and the effects of climate change, there is an emphasis on providing simple and practical solutions for the consequences of environmental damage instead of understanding the reasons why it is occurring. According to a report released by the (World Bank, FAO and IFAD 2015) the amount of waste produced in sub-Saharan Africa and Asia during 2016 is anticipated to increase to 3.4 billion tons in 2050. The World Bank report also highlighted that an improvement in the management of solid waste is an urgent priority, especially in low-income countries. The report showed that more than 90 percent of waste in low-income countries is left unprocessed in open areas because of inadequate waste disposal and treatment facilities. Such a situation poses problems for the health of ecosystems and humans. The report also maintained that the issue of solid-waste management should be dealt with seriously in high-income countries. This is because such countries are responsible for one-third of the world's waste, although the population of such countries only constitute 16 percent of the world's population. It is estimated that in 2030, China will produce double the amount of urban waste than the USA. Again, according to the World Bank report, if such a situation continues, in 2050, the amount of waste in South Asian countries will double its current amount and triple in sub-Saharan African countries. According to the World Bank report it is declared that by 2050, the world population will be expected to begin living in cities. According to the published report, while the amount of waste per capita per day was 0.64 kilograms in the period when 2.9 billion inhabitants lived ten years ago, this figure is expected to increase up to 1.2 kilograms today. The report also warns that the urban population, which will progress to 4.3 billion people in 2025, will raise the amount of waste per person per day to 1.42 kilograms ("World Bank, Sub-Sahara", 2018). According to Öztürk (2018), the worldwide search for short-term solutions related to air, water, and soil pollution was triggered when such pollution reached limits that would endanger all living things. According to the World Bank reports, if pollution trends persist, the amount of domestic waste, which is currently 1.3 billion tons per year, is expected to reach 2.2 billion tons in 2025 .

In Turkey, $52 \%$ of domestic waste is organic waste, $6 \%$ is plastic waste (of which a huge part is plastic bags), $10 \%$ of domestic waste is paper and cardboard waste, $4 \%$ is glass waste; $2 \%$ is metal waste, and the rest consists of other waste. When 
looking at the ratios of domestic waste it can be seen that a significant portion of waste can be recovered and converted into new products (Öztürk, 2018). Developed and developing countries and even underdeveloped countries have recognized the seriousness of domestic waste as an issue, and have engaged in various efforts and activities to remedy the situation. In this regard, many countries have prepared and implemented a wide range of educational projects to educate their communities about domestic waste based on the idea that the most critical problem is the lack of education available.

The purpose of recycling is to ensure that resources are not used unnecessarily, that waste is recycled and reused, and that garbage is minimized by separating waste from its raw source (UNESCO, 1992). Recycling preserves the surrounding natural resources and also reduces the amount of solid waste. It is also a useful resource recovery mechanism, with considerable economic and environmental benefits (Hopper and Nielsen, 1991; Oskamp, 1995; Valle, Reis, Menezes, and Rebelo, 2004).

The zero-waste approach in recycling studies is known as the waste-prevention approach. Such an approach covers more efficient use of resources, reduces the amount of waste generated, and recycles waste (Environment and Urban Ministry, 2017). Carver, one of the pioneers of the concept of zero waste, stated in an article he published during his undergraduate education in 1893, that there was no waste material in nature. Presentations were made to explain how much waste, from tree leaves to farm manure, could be used again either as raw materials or in another form. He described the waste as "another source in disguise" (Anonymous, 2009).

It is essential for the future survival of the world's environments for people to support zero-waste and recycling approaches. Such approaches will yield a cleaner, healthier and more prosperous world in terms of the availability of natural resources for all communities. Education programs to raise awareness about zerowaste and recycling is necessary for many communities. Within this context, it has become an essential responsibility for every society to alter their consumption habits and develop awareness about the implications for every material that is consumed. It is time to take a critical approach towards becoming a conscious consumer and evaluate the value of recycled waste compared to using resources and then throwing them away. The concepts of zero-waste and recycling have become an inescapable phenomenon to present a clean environment and a livable world for all living things. For all these reasons, providing opportunities for children in their pre-school education years to develop environmental awareness about zero-waste is the initial step in formal education programs. It will be a small step locally but a big step overall for the future of the world. The 21st century intends to solve economic, cultural, environmental, and social problems together following sustainable common goals and values all around the world (Salonen \& Tast, 2013). In this context, and within the framework of sustainable development plans, such values should be gained to children at an early age because they are competent individuals with their own identities (Samuelsson, 2011).

The pre-school education years should be aimed at helping children to understand how to solve environmental problems and develop unique, creative, and practical solutions to current issues. This is because pre-school education is where 
children experience formal education for the first time and are introduced to their future educational life. Pre-school education is a critical period covering 0-66 months of childhood, during which children's learning is rapid, basic behaviors are gained, and social, cognitive, and language developments are rapidly changing (Çetinkaya, 2006; Azkeskin and Güven, 2010, Uluyurt, 2012). In addition, pre-school education helps children to acquire basic habits by providing them with learning opportunities so that they can learn by living and doing (Aktaş, 2002 and Yumuş, 2013). Children have many feelings of curiosity and discovery in the pre-school years. Pre-school education institutions contribute to children's development by providing them with environments where they can learn by exploring in accordance with their developmental level (Yeşilyurt, 2011). The priority for children in preschool education is the development of problem-solving, decision making, and conceptualization skills (Büyüktaşkapu Soydan and Dereli, 2014). Since it is not possible for children to develop problem-solving skills on their own, a natural and artificially prepared environment together with hiring individuals trained in this area are needed to help children develop the skills of exploration and discovery (Rivera, 2009). The early childhood years are a time of unique growth and development (Rahmayanti, Oktaviani and Syani; 2019).

In Turkey, it is observed that no awareness programs about the concept of zerowaste are included in the current pre-school education program. On the other hand, it has been determined that recycling-related activities and skills are included in pre-school education programs which are aimed at ensuring children's cognitive, social, and emotional development. In this process, it was determined that children were provided with posters for glass, plastic and paper recycling; they were also provided with cards which had a recycling symbol, and photographs of trash recycling bins with symbols of glass, plastic bottles, and paper (Meb, 2013). Environmental awareness occurs through recycling programs in pre-school education (Çimen and Yılmaz, 2012). Thus, while the living environment remains clean, the natural resources are protected and the amount of waste is reduced. It contributes to the economy by saving money and by reducing the amount of waste (Karatekin and Merey, 2015). In addition, recycling resulting from the reuse of waste materials is very important to prevent environmental problems and minimize the waste of resources (Hopper and Nielsen, 1991).

The percentage of all activities in a preschool curriculum that focuses on environmental education in various countries and Turkey are distributed in the following way. The percentage of environmental education activities in Germany's pre-school education program is $100 \%$, and the percentage of environmental education activities in Switzerland's program is $37 \%$. It is observed that $22 \%$ of environmental education activities occur in Japan's pre-school education program and $19 \%$ of activities in Canada's program relate to environmental education. The percentage of environmental education activities in the United States of America's program is $14 \%$. The percentage of environmental education activities in Turkey's pre-school education program is 23\% (Akçay, 2006, Öztap, 2019).

When assessed from this point of view, it is observed that other countries have a much smaller percentage of environmental education activities in pre-school education programs compared to Germany. Additionally, as a result of web searches, 
it is recognized that some non-governmental organizations and institutions have adopted the concept of "zero-waste" as a target in the world, however, no information about the concept of "zero-waste" is discovered in the existing preschool education programs.

It is a fact that human beings need to use the world's natural and economic resources more effectively than ever. In this regard, it is very important to raise awareness in societies starting from the pre-school education years. An awareness about zero-waste and recycling activities to be gained by children during their preschool education years will grow with them and will be one of the most important arguments for creating and maintaining a more livable world. Pre-school teachers play a crucial role in developing environmental attitudes and understanding amongst pre-school children (Pressoir, 2008). In this period, when pre-school teachers can give more prominence to zero-waste and recycling studies it presents precious opportunities for children to learn-by-doing and living, and to also gain environmental awareness at an early age. The current research about awareness of zero-waste and recycling activities in the pre-school education years is essential because it will add to the field globally in terms of its results; it will also guide all education stakeholders who are interested in the subject to create awareness about the subject and guide further empirical work. Furthermore, according to data obtained from the literature review, it is observed that while there is no awareness about zero-waste in pre-school education programs in Turkey, there is limited awareness about recycling activities. As a result of the research, it is seen that, in pre-school education programs from countries such as Switzerland, Japan, Canada, and the United States of America, there are no activities linked with zero-waste. Recycling-related activities, are introduced although their presence in pre-school education programs varies. For this reason, the study is also critical because findings will support and encourage all countries to make room for zero-waste and recycling activities in pre-school education programs. Furthermore, the study is necessary to raise awareness levels about zero-waste and recycling activities for pre-school education teachers. Also, it is defined in the literature, there is no study to determine teachers' opinions about raising awareness of zero-waste and recycling activities amongst children during pre-school education both in Turkey and in the aforementioned countries. Therefore, this study is anticipated to fill such a gap in the literature.

The research question investigates the lack of inclusion about zero-waste in preschool education programs, the limited awareness about recycling, and possible solutions about the type of activities that can help raise awareness about zero-waste and recycling by pre-school children. The general purpose of this study is to guide teachers about what can be involved in promoting awareness about the concept of zero-waste and recycling in pre-school education programs, and to ascertain opinions from teachers about what can be done to help develop awareness about zero-waste and recycling in the pre-school education years. According to this purpose, answers were investigated for the following sub-questions.

- Are the activities for zero-waste and recycling awareness enough for children in pre-school education programs? Why? 
- What can be taught differently about zero-waste and recycling in pre-school education institutions? Can you explain?

- How should zero-waste and recycling education be given to children in preschool education institutions?

- What kind of hands-on activities can children be given in a learning environment in relation to zero-waste and recycling? Can you explain?

- If you have any opinions you would like to add to the subject, please specify.

\section{Methodology}

\section{Research Design}

The research design is a qualitative case study method. According to Creswell (2007), case studies are a qualitative research approach in which the researcher examines one or several situations constrained over time in-depth with data collection tools involving multiple sources and identify situations and situationrelated themes. Hancock and Algozzine (2006) define case studies as the studies based on deep foundations that enrich the events occurring in their natural conditions by using various data collection tools under time and space constraints. According to Yin (2009), a case study necessitates researching a situation in real life's current context or environment while Stake (1995) states that case study research is not a methodology but a choice about what to study, other researchers recommend that it is a research strategy, a methodology, or a comprehensive research strategy (Merriam 1998 \& Yin, 2009).

\section{Study group}

The research participants or study group are pre-school teachers who served in a province of Turkey in the 2018-2019 academic year. In this research, a criterionsampling method, which is a purposeful sampling method, was applied. In the research, the determining criteria are teachers who hold at least five years of experience in the profession as a pre-school teacher, and have received training about zero-waste and recycling either during their service as a teacher or before being appointed to the profession. Forty pre-school teachers were chosen from the criterion-sampling method and volunteered to participate in the research. All cases satisfied the set of predetermined criteria. The researcher created a criterion or a list of previously prepared criteria to be employed (Marshall \& Rossman, 2014). Criterion-sampling is not only arranged with the time variable; any situation that is the subject of the research can be defined as a criterion (Grix, 2010). In the current study, $80 \%$ of the teachers are female and $20 \%$ of them are male; $60 \%$ of the teachers are in the 35-40 age range and 25\% are between the ages of 40-45 years. Only $10 \%$ of teachers in the study are 45 years and over, and $5 \%$ are between $30-35$ years. On the other hand, $45 \%$ of teachers in the study have 10-15 years of professional seniority, $25 \%$ have between $15-20$ years of professional seniority, and $12.5 \%$ are between 20-25 years of professional seniority, whereas $10 \%$ have professional seniority of 25 years or more, yet only $7.5 \%$ have between 5 to 10 years in their profession. 


\section{Data Collection Tools}

In the current research, a semi-structured interview was conducted with each participant to determine the number of activities occurring about zero-waste and recycling in pre-school education programs, and what the related activities should be. In the semi-structured interview, open-ended questions were used to collect abundant and sufficient information so as to enable comparison and analysis of responses (Breakwell, 1995).

\section{Collection and Analysis of Data}

The data were obtained through face-to-face semi-structured interviews with pre-school teachers. Stewart and Cash (1985) described the semi-structured interview as a mutual and interactive communication process based on the style of asking and answering questions for a serious purpose. According to Patton (2005), the purpose of the semi-structured interview is to infiltrate the inner world of the individual and to comprehend his perspective on the events. Qualitative interviews require the researcher to pose questions to an interviewee who, in their replies, are permitted or encouraged to digress, to expand on their views, to exemplify their points, and to introduce their own concerns. In semi-structured interviews, the researcher has prepared various questions, and will guide the conversation to a greater degree than in unstructured interviews (Zahle, 2019).

In order to increase the reliability of the semi-structured interview used in this study, three experts were consulted: two from the education programs and education department at the university, and one in the pre-primary education department. Following the advice provided by the experts, the questions for the semi-structured interview were revised and the order of the questions were rearranged. To test the validity and usefulness of the questions, the semi-structured interviews were conducted as a pilot practice with seven pre- school teachers who were excluded from entering the research sample. The consistency rate between the researcher and experts from the field were examined to ensure the reliability of the data; consistency rates were based on the formula (Consensus / (Consensus + Disagreement) $x$ 100) which was developed by Miles and Huberman (1994) and frequently applied in qualitative studies. The consistency rate from the pilot study was determined to be above $85 \%$. Later, the data were converted into tables and showed as frequency (f) and percentage (\%). During the content and descriptive analysis of the data, the data were classified and analyzed by hand, and no software program was applied in this process.

Later, the semi-structured interviews, lasting approximately 50 minutes, were carried out by the researcher making an appointment with each participant and going to the schools where they worked. Therefore, the semi-structured interviews were conducted face-to-face. An audio-recorder was utilized to prevent data loss during the interview. In analyzing the obtained data, content analysis and descriptive analysis approaches were applied together, and the data were abstracted and interpreted. In content analysis, studies on a specific subject are discussed, and trends and results of these studies are evaluated descriptively and systematically (Lin, Lin, \& Tsai, 2014). The goal of the content analysis is to collect 
similar data under certain concepts and themes and organize and explain them in a way that people can understand (Yıldırım and Şimşek, 2011). Falkingham and Reeves (1998) also stated that content analysis is a new method for evaluating publication stacks. In the descriptive analysis, the goal is to describe how an event happens and proceeds, or what a situation looks like and to try to make complicated things more understandable (Patton, 2005). Identifying information about the participants was not included because of confidentiality requirements. Instead, codes such as "teacher 1 , teacher 2 (T1; T2)" were employed. Direct opinions of the participants are reported to strengthen the validity of the research (Yildırım \& Şimşek, 2011). In this study, a qualitative research approach was used to collect detailed and in-depth data, to learn participants' individual perceptions, experiences and perspectives directly, to understand and explain current situations about awareness and inclusion of zero-waste and recycling activities in pre-school education programs (Büyüköztürk, Kılıç Çakmak, Akgün, Karadeniz and Demirel, 2014).

\section{Findings}

The data obtained from the interviews with pre-school teachers were presented as tables. The research findings and tables are organized under five headings based on each interview question. These titles are as follows: "Is zero-waste and recycling awareness sufficient for children in pre-school education programs?"; "What can be taught differently about zero-waste and recycling in pre-school education institutions?; " How should zero-waste and recycling education be given to children in pre-school education institutions?"; "What kind of hands-on activities can children be given in a learning environment in relation to zero waste and recycling?"; and "Other opinions that teachers would like to add to the subject.". Table 2 shows the teacher's opinions about the level of sufficiency in awareness about zero-waste and recycling gained by children in pre-school education programs.

Table 2

Teachers' Opinions on The Level of Sufficiency in Awareness About Zero-Waste and Recycling Gained by Children in Pre-School Education Programs

\begin{tabular}{llll}
\hline Theme & Codes & F & $\%$ \\
\hline & & 40 & $\% 100$ \\
\hline $\begin{array}{l}\text { opinions on the level of } \\
\text { sufficiency of zero }\end{array}$ & Sufficient & 4 & $\% 10$ \\
waste and recycling & Partially sufficient & 11 & $\% 27.5$ \\
Awareness & Insufficient & 25 & $\% 62.5$ \\
\hline $\begin{array}{l}\text { opinions on the reasons for } \\
\text { raising zero waste }\end{array}$ & & 40 & \\
and recycling awareness & & & \\
\hline & Contribution to the country's economy & 25 & $\% 62.5$ \\
& Raising awareness at an early age & 16 & $\% 40$ \\
& Protecting nature and the environment & 11 & $\% 27.5$ \\
& running Out of resources & 8 & $\% 20$ \\
& Protecting all living things & 7 & $\% 17.5$ \\
\hline
\end{tabular}


When Table 2 is analyzed, the teachers' opinions on the sufficiency level awareness about zero-waste and recycling amongst children in pre-school education programs, are found to be "insufficient" (f:25- 62.5\%), "partially sufficient" (f:11- \%27,5) and "sufficient" (f: 4- 10\%). Teacher No.5 answered "insufficient" supported by the opinion that "There is no gain regarding zero-waste in pre-school education years, which is desired to be provided to children in existing programs. However, there are activities related to recycling that are prepared for children according to their cognitive development levels. We have children do these activities, but I don't think they are enough." Teacher No.18 answered "partially insufficient" supported by the opinion that "There are studies on recycling and use of waste materials in our programs. I'd say they meet the same need, in part." Teacher No.27 answered "sufficient" supported by the opinion that "I think the activities given in our current training programs on this subject are adequate. Children may have difficulty learning more."

Upon continued examination of Table 2, teachers' views about the reasons for raising awareness about zero-waste and recycling amongst children in pre-school education programs are listed as "contribution to the country's economy" (f:25$\% 62.5$ ), "raising awareness at an early age" (f:16-\%40), "protecting nature and the environment" (f:11-\%27.5), "running out of resources" (f:8-\%20) and "protecting all living things" (f:7- \%17.5). Teacher No.40 answered "contribution to the country's economy" supported by the opinion that "I see the most important input of the country's economy as the reintroduction of waste materials to the economy through recycling." Teacher No.32 answered "raising awareness at an early age" supported by the opinion that "Raising awareness in children at an early age allows them to learn more permanently in such matters because 'as the twig is bent, so grows the tree'". Teacher No.15 answered "protecting nature and the environment" supported by the opinion that "We must all go hand in hand to leave a clean future and a cleaner and more livable world for our children, and we must take care of all kinds of work on zero waste and recycling". Teacher No.13 answered "running out of resources" supported by the opinion that "It seems to me that we will not even find a tree to sit in its shadow in the near future. In order to stop this situation, we should support recycling from all ages and all segments of society. "Teacher No.6 "protecting all living things" supported by the opinion that "Some species have begun to perish in nature. The ecological balance is broken. This situation is dangerous for the future." Teacher opinions about what more can be taught to children about zero-waste and recycling during the pre-school education years are given in Table 3.

Table 3

Teacher's Views About What Can Be Taught to Children About Zero-Waste and Recycling During the Pre-School Education Years

\begin{tabular}{|c|c|c|c|}
\hline Theme & Codes & $\mathrm{F}$ & $\%$ \\
\hline & & 40 & $\% 100$ \\
\hline opinions on & $\begin{array}{l}\text { Explaining the subject by enriching } \\
\text { content }\end{array}$ & 133 & $\% 82.5$ \\
\hline $\begin{array}{l}\text { what more can } \\
\text { be taught about }\end{array}$ & Explaining what can be recycled & 26 & $\% 65$ \\
\hline zero waste and & Explaining how the transformed it & e18 & $\% 45$ \\
\hline
\end{tabular}
recycled 
Bulut, A. (2020). Teacher Opinions about Children's Awareness of Zero-Waste and Recycling in...

$\begin{array}{llcc}\text { Recycling } & \begin{array}{l}\text { Giving children Work that will improve their15 } \\ \text { creativity }\end{array} & \% 37.5 \\ & \text { Benefiting the environment and nature } & 14 & \% 35 \\ & \text { Being a role model at home and school } & 11 & \% 27.5\end{array}$

When Table 3 is analyzed, the teacher's opinions about what more can be taught about zero-waste and recycling during the pre-school education years are: "explaining the subject by enriching visual content" (f: 33-82.5\%); "explaining what can be recycled" (f:26-65\%); "explaining how the transformed items are recycled" (f:18-45\%) and also, "giving children work that will improve their creativity" (f: 15$37.5 \%$ ); "benefitting the environment and nature" (f:14- 27.5\%); and "being a role model at home and school" (f:11-27.5\%). Teacher No.32 answered "explaining the subject by enriching visual content" supported by the opinion that "If the concepts of zero-waste and recycling are explained to children with a variety of images (animations, pictures, slides, and various visuals), it may be easier and more permanent for them to learn about the subject." Teacher No.10 answered "explaining what can be recycled" supported by the opinion that "We can explain to children how recycling materials such as plastic, metal, glass, paper, and batteries can be recycled and become useful by making simple application practices." Teacher No.15 answered "explaining how the transformed items are recycled" supported by the opinion that "Awareness can be raised about how the transformed items are recycled by organizing trips to recycling facilities and showing them on-site, or having them watch films about the subject". Teacher No.21 answered "giving children work that will improve their creativity" supported by the opinion that "Children can be given creative work to improve their creative thinking skills to recycle waste materials". Teacher No.21 also answered "benefiting the environment and nature" supported by the opinion that "We must explain that we do not live in nature alone, that nature is the home of other creatures, and that if we do not protect our environment, we will not find a place to play games when we grow up". Teacher No.9 answered "being a role model at home and school" supported by the opinion that "In zero waste and recycling, we as teachers should be a good role model for children as parents at home. As adults, we should show the children with our behavior that we care about this issue." Teacher's opinions about how to provide zero-waste and recycling education to children during the pre- school education years are given in Table 4.

Table 4

Teacher's Views About How to Provide Zero Waste and Recycling Education to Children During the Pre-School Education Years

\begin{tabular}{llll}
\hline Theme & Codes & $\mathrm{F}$ & $\%$ \\
\hline opinions on how & & 40 & $\% 100$ \\
to provide zero & Teaching by playing educational games & 28 & $\% 70$ \\
waste and & Teaching with drama method & 14 & $\% 35$ \\
Recycling & Getting expert support & 14 & $\% 35$ \\
$\begin{array}{l}\text { Education } \\
\text { during pre- }\end{array}$ & Providing family participation & 8 & $\% 20$ \\
School Education & Teaching with 5E model & 8 & $\% 20$
\end{tabular}


When Table 4 is analyzed, the teacher's opinions about how to provide zerowaste and recycling education to children during the pre-school education years are: "teaching by playing educational games" (f:28-70\%); "teaching with drama method" (f:14-35\%); "getting expert support" (f:14-35\%); "providing family participation" (f:8-20\%); and "teaching with 5E model". Accordance with opinions about how to provide zero-waste and recycling education to children during the preschool education years, Teacher No.17, answered "teaching by playing educational games" supported by the opinion that "We can teach zero waste and recycling studies through educational games to increase active learning and reinforce learning in children.". Teacher No.30 answered "teaching with drama method" supported by the opinion that "In teaching such subjects, it can be very useful to use the method of drama, where the child can easily develop his/her creativity and personality by creating educational environments where he/she can express themselves freely, and learn-by-doing.". Teacher No.30 also answered "getting expert support" supported by the opinion that "During this period, I think it would be more beneficial if children were given zero-waste and recycling awareness by subject specialists and assistance may be requested from universities or nongovernmental organizations on the subject." Teacher No.4 answered "providing family participation" supported by the opinion that "I think it is very important for families to support the learning process given at school with their behaviors and actions since the children spend most of their time at school and at home during this period.". Teacher No.23 answered "teaching with 5 E model" supported by the opinion that "As children learn about zero waste and recycling, we can get them to come up with new ideas with their friends by taking part in events that will draw their attention to the subject, and by listening to these new ideas that they have produced, as teachers, we can go over the important points that need to be highlighted if any. However, based on the knowledge that students have already learned about the subject, we can evaluate their performance by conducting studies in which they can apply this learning if they encounter a new problem." Teachers' feedback about what kind of practical activities children can have in the learning process about zero-waste and recycling are given in Table 5.

Table 5

Teachers' Opinions About What Kind of Practical Activities Children Can Have in the Learning Process About Zero-Waste and Recycling

\begin{tabular}{|c|c|c|}
\hline Theme & Codes & $\%$ \\
\hline & 40 & $\% 100$ \\
\hline \multirow{5}{*}{$\begin{array}{l}\text { Opinions on what } \\
\text { different types of } \\
\text { practical activities } \\
\text { can be done } \\
\text { regarding zero } \\
\text { waste and recycling }\end{array}$} & $\begin{array}{l}\text { Making recycling bins to be used in } \\
\text { classrooms }\end{array}$ & $\% 90$ \\
\hline & $\begin{array}{l}\text { Preparing and displaying brochures that } 28 \\
\text { will raise awareness }\end{array}$ & $\% 70$ \\
\hline & $\begin{array}{l}\text { Organizing nature and environmental22 } \\
\text { trips }\end{array}$ & $\% 55$ \\
\hline & $\begin{array}{l}\text { Participating in artistic events about the } 16 \\
\text { subject }\end{array}$ & $\% 40$ \\
\hline & Making toys from recycling materials & $\% 15$ \\
\hline
\end{tabular}

When Table 5 is analyzed, the teacher's opinions about what kind of practical activities children can have in the learning process about zero-waste and recycling are: "making recycling bins to be used in classrooms" (f:36-90\%); "preparing and 
displaying brochures that will raise awareness" (f:28-70\%); "organizing nature and environmental trips" (f:22-55\%); "participating in artistic events" (f:16-40\%); and "making toys from recycling materials" (f:6-15\%). Teacher No.8 answered "making recycling bins to be used in classrooms" supported by the opinion that "By making recycling bins in different colors from waste materials together with children in our classrooms, we can enable them to throw waste materials such as paper, glass, plastic, and batteries to these bins.". Teacher No.26 answered "preparing and displaying brochures that will raise awareness" supported by the opinion that "In our classrooms, we can prepare brochures that will raise awareness about zerowaste and recycling in children and display them by hanging them to the places that will attract the attention of students in the school and the classroom.". Teacher No.3 answered "organizing nature and environmental trips" supported by the opinion that "We can arrange trips to recycling-related workshops and businesses around us, if there is any.". Teacher No.28 answered "participating in artistic events" supported by the opinion that "Children can participate in artistic activities (theatre, cinema, book reading) organized around them on the subject." Teacher No.40 answered "making toys from recycling materials" supported by the opinion that "Award-winning project works can be made for children to make their own toys with recycling materials." Other opinions that pre-school teachers want to add to the subject about zero-waste and recycling in the pre-school education year are given in Table 6.

Table 6

Other Opinions Teachers Want to Add to the Subject About Zero-Waste and Recycling in the Pre-School Education Years

\begin{tabular}{llcl}
\hline Theme & Codes & F & $\%$ \\
\hline & & 40 & 100 \\
\hline $\begin{array}{l}\text { Other opinions that pre- } \\
\text { school teachers want }\end{array}$ & Zero waste concept should be included in pre-9 & $\% 22.5$ \\
to add to the subject & school education programs & $\% 17.5$ \\
& $\begin{array}{l}\text { Recycling-related gains should be more } \\
\text { included in the programs }\end{array}$ & \multicolumn{2}{c}{7} \\
\hline
\end{tabular}

In accordance with Table 6, the other opinions from teachers about what they wanted to add to the subject of zero-waste and recycling in the primary school years, are as follows; "zero waste concept should be included in pre- school education programs" (f: 9-22.5\%); and "recycling-related gains should be more included in the programs" (f:7-17.5\%). Teacher No.12 answered "zero-waste concept should be included in pre-school education programs" supported by the opinion that "There are no gains related to the concept of zero waste in the current pre-school education program. I think that such an important issue should be included in educational programs.". Teacher No.34 answered "recycling-related gains should be more included in the programs" supported by the opinion that "I do not think that the gains in pre- school education programs related to recycling are sufficient."

\section{Conclusion and Discussion}

Article text. Most of the teachers stated that insufficient levels of awareness about zero-waste and recycling were gained by children during their pre-school education. Teachers have explained and listed their reasons for wanting to raise awareness about zero-waste and recycling amongst children in pre-school education programs 
as being related to contributing to the country's economy, raising awareness at an early age, protecting nature and the environment, saving the country's natural resources and protecting all living things in the environment. A similar study conducted by Onur, Çağlar, and Salman (2016) supports the results of the current research because it was observed that the pre-school children did not have sufficient information about the environment, recycling, and environmental protection. Gülay and Ekici (2010) also stated that the objectives, achievements, and concepts for environmental education are inadequate in the pre-school education program. These scholars stated that the pre-school education programs in environmental education are not sufficient enough for teachers to raise awareness in children about how to contribute to the economy of the country, how to be sensitive to nature and environment in which they live, how to see nature as the home of all living things and how to be conscious about zero-waste and recycling. The current study will enable a review of awareness about zero-waste and recycling in pre-school education programs to occur amongst all relevant educational stakeholders. Besides, teachers stated that awareness about zero-waste and recycling amongst children during their pre-school education years, will be essential for helping them to understand how to contribute to the national economy, preserve nature and the environment, protect the resources before they run out, and maintain the life of all living creatures. It should be noted that teachers consider the concepts of zerowaste and recycling as a strong element that combines phenomena such as economy, environment, and life, which is considered to be among the essential needs of all people.

Teachers stated that the children's level of awareness about zero-waste and recycling can be enhanced by enriching the lessons with visual materials and content, and explaining what can be recycled, and how to recycle. Teachers in the current study also stated that they can provide children with activities to: improve their creativity with using waste materials; explain the benefits of zero-waste and recycling to the environment and nature; and also, to be role models at home and at school. As can be seen, teachers have drawn attention to the need of using more intensive educational materials that will make the learning and teaching process more accurate and understandable, while helping children to develop their awareness about zero-waste and recycling. The research findings emphasize the idea that teachers should be much more creative, and should present opportunities for children to learn-by-doing and learn-by-living whilst performing activities intended to promote awareness about zero-waste and recycling.

In the pre-school education years, teachers can be said to highlight the educational games and drama that transform abstract experiments into concrete experiments. Such an approach will help children to establish connections between learnings and make the learning process more enjoyable whilst promoting awareness about zero-waste and recycling. Such an approach is also considerate of pre-school children's age and development levels. Learning by using games can provide more relaxed conditions for learning, and with this, children will not experience fatigue of learning because the material presented in this game model is really a form of a game (Darmawan, 2013). Educational games that are used as learning media, besides being able to increase learning motivation, can also improve 
student learning outcomes (Hung, Huang., and Hwang, 2014). Educational games have exceptional significance in fulfilling the goals and behaviors intended to be achieved by the learner (Amory, 2001; Amory, Naicker, Vincent, \& Adams, 1999; Moreno Ger, Burgos, Martínez- Ortiz, Sierra, \& Fernández-Manjón, 2008). According to Edwards \& Mackenzie (2013) a game-based pedagogical model for thinking about environmental education in early childhood education is suitable because it suggests how to implement combined types of play to relate to and further support the teaching and learning about environmental education.

Furthermore, educational games are thought to encourage students to focus on the subject, boost their motivation and interest in the lesson, and present more powerful and permanent learning moments (Cira, Chung, Denisin, Rensi, Sanchez, Quake and Riedel Kruse, 2015; Hsu \& Tsai, 2013). In this sense, teachers have important roles, and duties as a guide and as a play-mate for children during the preschool education years (Edwards, \& Cutter-Mackenzie, 2011). For this reason, the fact that teachers teach zero-waste and recycling concepts to children as their playmate in the pre-school education years will make the learning process more qualified and perpetual. Teachers stated that the concept of zero-waste and recycling should be taught to children by enriching them with visual education materials and content during the pre-school education years. Teachers stated that in this process, they can encourage children to learn-by-doing and learn-byexperiencing so as to develop their creativity. In relation to this process, teachers also stated that they could provide active learning opportunities for children and also provide collaborative learning environments. On the other hand, it can be said that teachers draw most attention to the importance of providing visual materials and content-enriched learning environments to help raise children's awareness about zero- waste and recycling during pre-school education. In addition, work on zero-waste and recycling during the pre-school education years can also help raise children's awareness about nature and the environment.

Teachers stated that they could use educational play-way methods in the learning and teaching process in order to help children develop awareness about zero-waste and recycling activities in the pre-school education years. Teachers have expressed that they can use the educational play-way methods to help children transform their abstract lives into their concrete lives, and to make the learning process about zerowaste and recycling awareness more fun and interesting. Teachers consider educational play-way methods as the most appropriate method for teaching the concepts of zero-waste and recycling in terms of the children's age and level of development. Games used in the educational process must be prepared with concrete materials and be appealing to multiple sensory organs and suitable for students' age groups (Usta et al., 2017). In this way, educational games enable more effective classroom learning (Alıcl, 2016). Additionally, the teachers stated that drama could also be used to help bring awareness to children about zero-waste and development, and expert support can be obtained, family participation can be provided, and the subject can be taught using the 5E model. Based on these results, the reason why teachers highlight drama as a method they will use the most in bringing awareness about zero-waste and recycling activities to children may be due to the idea that drama will positively affect language development in children due 
to the high-level thinking skills required. Similar to the results of this study, it's known that the use of drama in the learning environment improves children's thinking skills, social development and collaboration habits, creativity, aesthetic development, critical thinking skills, verbal and written communication skills (Erdem and Aydos \& Gönen, 2017; Chiriga, 1997; Rances, 2005; Turner et al., 2004; Yaffe, 1989). According to Temel and Türkoğlu (2019), it was ascertained that drama activities employed in pre-school education are essential in terms of "supporting the learning process by doing and living" and "supporting the social learning process" of children. Additionally, teachers stated that while providing children with opportunities to develop their awareness about zero-waste and recycling in class-time, support can also be obtained from subject specialists, and families can participate in the studies related to the subject so that the learning process is supported by all education stakeholders. According to the literature, it was determined that family participation positively affects children's developmental and academic lives in the pre-school education years (Toran \& Özgen, 2018; Ma and Shen, \& Krenn., Hu, Yuan., 2016; Mazer and Thompson, 2017; Ünüvar, 2010; Tezel Şahin ve Turla, 2003; Nitecki, 2015; Kartal, 2007). Teachers from the current study stated that providing opportunities for children to develop their awareness about zero-waste and recycling is not only a learning process to occur at school, but that families should also participate in this education process. Teachers have indicated that they can use the 5E model to improve children's problem-solving skills as another method to help children develop awareness about zero-waste and recycling. The 5E learning model enables students to explore new concepts and fuse them with their previous knowledge (Ekici, 2007). Furthermore, the teaching activities carried out with the $5 \mathrm{E}$ model helps students to organize their own knowledge in a way that allows them to create their own knowledge in case of any problems (Türker, 2009). Research results obtained from this study are supported by Buntod, Suksringam, and Singseevo (2010), Bıyıklı and Yağcı's (2014) study which determines that the $5 \mathrm{E}$ learning model is supported by cognitive techniques to improve students' scientific processing skills. The 5E model consists of activating students' prior knowledge about the subject (Engage); then discovering new information (Explore) and helping children to apply and make sense of the information they have learned (Explain); then there is the opportunity to deepen and transfer the new knowledge to real-life (Elaborate) and finally evaluate their learning (Evaluate) (Bybee., Taylor., Gardner., \& Van-Scotteer., Powell, Westbrook., and Landes, 2006). In the pre-school education years, by applying the 5E model to zero-waste and recycling will enables children to actively use their knowledge and skills and responds to their personal interests and needs, which can have a positive effect on the social and cognitive development of children.

The teachers stated that in the pre-school education years, they could have recycling boxes in their classrooms, prepare brochures and arrange exhibitions, and organize nature and environmental trips in order to assist children with developing a sense of awareness about zero-waste and recycling.

It has been determined that the answers given by pre-school education teachers about what kind of activities can be done to help pre-school children develop awareness about zero-waste and recycling varies. In this context, they stated that 
they could have recycling bins in the classrooms, prepare brochures on the subject and organize exhibitions, and develop nature and environmental trips. The preschool education teachers also noted that they could have children participate in artistic events on the subject and make toys from recycling materials. Teachers have stated that their efforts to raise children's awareness about zero-waste and recycling in the learning and teaching process will have a positive impact on their social and emotional development and problem-solving skills. Denham et al., (2003), in his research about the contributions of the emotional competence of pre-school children to social development, concluded that emotional competence of children aged three to four contributes to and social competence in the long run.

In addition to their previous opinions, pre-school teachers who participated in the study also stated that the concept of zero-waste should be included in pre-school education programs, and recycling-related gains should be more involved in preschool education programs. In order to shape the future of countries in all regards and leave a cleaner environment for future generations, more importance should be assigned to zero-waste and recycling matters in the pre-school education years. In conclusion, the concepts of zero-waste and recycling activities are significant universal gains in order to shape the future of countries in every way and to leave a clean environment for future generations. In this context, it is seen that teachers express, with a critical approach, the fact that awareness about the concept of zerowaste are not included in pre-school education programs and that the opportunities for recycling activities are very limited. Based on the results of this study, regarding the research process;

- Giving emphasis to the concept of zero-waste in pre-school education programs can be an essential step in raising awareness of children at an early age.

- The levels of awareness about recycling activities in pre-school education programs can be increased.

- Teachers can explain the issues related to zero-waste and recycling by enriching the learning environment with visual materials and content.

- Teachers should explain the concepts related to zero-waste and recycling by establishing connections between the reasons and the way they create events (Deductive); for this reason, they should seek to improve their awareness and attention in solving the problems associated with the subject.

- It may be more useful for teachers to teach about zero-waste and recycling activities by using educational play methods to make learning enjoyable and more concrete in terms of the age and level of development of the children.

- Other teaching methods and techniques, such as drama and the 5E model, where children can learn-by-doing and experiencing, can also be used in the teaching of concepts related to zero-waste and recycling in pre-school education.

- Experimental or operational studies linked with zero-waste and recycling may add to the field during the pre-school education years. 
- The quality of learning by pre-school education teachers about the awareness of zero-waste and recycling activities can be increased by providing specialist support and encouraging family participation.

- There is a positive contribution from zero-waste and recycling activities in the pre- school education period on the social and emotional development of the child.

\section{References}

Akçay, İ. (2006). Environmental education for pre-school and elementary students in different countries (Master's thesis). Uludağ University Graduate School of Social Sciences, Bursa.

Aktas, Y. (2002). Mathematics education in preschool period. Adana: Nobel Tip.

Alıcl, D. (2016). A research on the effects of educational games in science and technology course on students' academic achievement and knowledge retention (Unpublished Master's Thesis). Kahramanmaraş Sütçü İmam University. Institute of Science, Kahramanmaraş.

Amory, A. (2001). Building an educational adventure game: Theory, design and lessons. Journal of Interactive Learning Research, 129 (2/3), 249-264.

Amory, A., Naicker, K., Vincent, J., \& Adams, C. (1999). The use of computer games as an educational tool: Identification of appropriate game types and game elements. British Journal of Educational Technology, 30(4), 311-321.

Amy Cutter-Mackenzie \& Susan Edwards (2013). Toward a model for early childhood environmental education: foregrounding, developing, and connecting knowledge through play-based learning. The Journal of Environmental Education, 44 (3), 195-213, DOI: $10.1080 / 00958964.2012 .751892$.

Anonymous (2009). Directive 2009/125/EC of the European Parliament and of the Council of 21 October 2009 establishing a framework for the setting of ecodesign requirements for energy-related products. Strasbourg, France: The European Parliament and the Council.

Azkeskin, K. E. \& Güven, G. (2010). Early childhood education and pre-school education. In İ. Diken (ed.). Early childhood education. Ankara: Pegem A.

Bıyıklı, C. \& Yağcl, E (2014). The effect of 5e learning model designed according to learning experiences on the science process skills. Ege Journal of Education, 15 (1) 45-79.

Breakwell, G. (1995). Introduction to research methods in psychology. In Breakwell, Hammond and Fife-Shaw (Eds). Research methods in psychology. Bin Meșe, CA: Adaçayl.

Buntod, P.C., Suksringam, P. ve Singseevo, A. (2010). Effects of learning environmental education on science process skills and critical thinking of mathayomsuksa 3 students with different learning achievements. Journal of Social Sciences 6 (1), 60-63.

Büyüköztürk, Ş., Kılıç -Çakmak, E., Akgün, Ö. E., Karadeniz, Ş. \& Demirel, F. (2014). Scientific research methods. Ankara: PegemA.

Büyüktaşkapu, S., \& Dereli, H. M. (2014). A comparative examination of strategies aiming to improve thinking skills of children used by preschool teachers in different countries. Kastamonu Eğitim Dergisi, 22(2), 475-496. 
Bybee, R.W., Taylor, A.J., Gardner, A., Van Scotteer P. \& Powell, J.C., Westbrook, A., and Landes, N. (2006). The BSCS 5E instructional model: Origins, effectiveness, and applications. Colorado: Springs.

Çetinkaya, C. (2006). The diachronic and current position of pre-school education in Turkey (Master's Thesis). Yeditepe University, Institute of Social Sciences, İstanbul.

Chiriga, L. J. (1997). Creative dramatics as an effective strategy. (Unpublished Master's Thesis). University of Virginia, USA.

Çimen, O. \& Yılmaz, M. (2012). Primary school students' knowledge about recycling and recycling behaviour. Journal of Uludağ University Education Faculty, 25 (1), 63-74.

Cira, N. J., Chung A. M., Denisin, A. K., Rensi, S., Sanchez, G. N., Quake, S. R. \& Riedel Kruse, I. (2015). A biotic game design project for integrated life science and engineering education. Public Library of Science, 13(3). e1002110.

Cooper, J. (2005). Global agricultural policy reform and trade: environmental gains and losses, Cheltenham: Edward Elgar.

Creswell, J. W. (2007). Qualitative inquiry \& research design: Choosing among five approaches. (2. Baskı). USA: SAGE.

Darmawan, D. (2013). Metodologi Penelitian Kuantitatif. Bandung: PT Remaja Rosdakarya.

Denham, S., Blaır, K., Demlılder, E., Levitas, J., Sawyer., K., Auerbach, S. \& Queenan, P. (2003). Pre-school emotional competence: Pathway to social competence. Child Development, 74(1), 238-256.

Edwards, S. \& Cutter-Mackenzie, A. (2011). Environmentalising early childhood education curriculum through pedagogies of play. Australasian Journal of Early Childhood, 36 (1), 51-59.

Ekici, F. (2007). The effect of the course material prepared according to the 5 E learning cycle in accordance with the constructivist approach on high school 3rd grade students' understanding of oxidation-reduction reactions and electrochemistry topics. (Unpublished Master's Thesis). Gazi Üniversity, Ankara.

Erdem, A. Ü., Aydos, E. H. \& Gönen, M. (2017). The use of creative drama in early childhood Educational settings: an examination of Teachers' and candidate teachers' Perspectives. HAYEF Journal of Education, 14(1), 409-424.

Falkingham, L. T. \& Reeves, R. (1998). Context analysis a technique for analysing research in a field, applied to literature on the management of $\mathrm{R}$ and $\mathrm{D}$ at the section level. Scientometrics, 42(2), 97-120.

Gadiraju, T. (2016). Investigating the determinants of recycling behavior in youth by using theory of planned behaviour (Master Thesis). Available from ProQuest Dissertations and Theses database. Retrieved from http://scholarcommons.usf.edu/etd/6085/

Grix, J. (2010). The foundations of research. London: Palgrave Macmillan.

Guide, V.D.R. L. N. \& Van Wassenhove. (2009). The evolution of closed-loop supply chain research. Operations Research, 57 (1), 10-18.

Gülay, H. \& Ekici, G. (2010). Environmental education of MEB preschool education program analysis. Turkish Journal of Science Education, 7 (1), 74-84.

Hancock, R.D. \& Algozzine, B. (2006). Doing case study research. New York: Teachers College Press. 
Hopper, J. R. \& Nielsen, J. M. (1991). Recycling as altruistic behaviour: Normative and behavioural strategies to expand participation in a community recycling program. Environment and Behaviour, 23 (2), 195-220.

Hsu, C. Y. \& Tsai, C. C. (2013). Examining the effects of combining self-explanation principles with an educational game on learning science concepts. Interactive Learning Environments, 21(2), 104-115.

Hung., C. M, Huang., I \& Hwang,. G. J. (2014). Effects of digital game-based learning on students' self-efficacy, motivation, anxiety, and achievements in learning mathematics Journal of Computers in Education 1, (2-3), 151-166.

Karatekin, K. \& Merey, Z. (2015). Attitudes of preservice social studies teachers towards solid wastes and recycle. Bayburt University Journal of Education Faculty, 10 (2), 297314.

Kartal, H. (2007. The effect of mother-child education program which is one of the early childhood education programs on cognitive development of six age children. İlköğretim Online, 6(2), 234- 248.

Kaya, K., Şenel, M. C. \& Koç, E. (2018). Evaluation of renewable energy sources in the world and Turkey, Technological Applied Sciences (NWSATAS), 13(3), 219-234. DOI:10.12739/NWSA.2018.13.3.2A0152.

Koç, E. \& Kaya, K., (2015). Energy resources-state of renewable energy. Mühendis ve Makina, 56, (668), 36-47.

Lin, T.C., Lin, TJ. \& Tsai, C.C. (2014). Research trends in science education from 2008 to 2012: A systematic content analysis of publications in selected journals. International Journal of Science Education, 36 (8), 1346-1372.

Ma, X., Shen, J., Krenn, H. Y., Hu, S., \& Yuan, J. (2016). A meta-analysis of the relationship between learning outcomes and parental involvement during early childhood education and early elementary education. Educational Psychology Review, 28(4), 771-801.

Marshall, C. \& Rossman, G. B. (2014). Designing Qualitative Research. New York: Sage.

Mazer, J. P., \& Thompson, B. (2017). The validity of the parental academic support scale: associations among relational and family involvement outcomes. International Journal of Quantitative Research in Education, 4(1-2), 120-132.

MEB, (2013). Preschool education program and activity book. Ankara: Anı.

Merriam, S. B. (1998). Case study research in education: A qualitative approach. San Francisco: Jossey: Bass.

Miles, M. B. \& Huberman, M. A. (1994). An expanded sourcebook qualitative data analysis. London: Sage.

Moreno-Ger, P., Burgos, D., Martínez-Ortiz, I., Sierra, J.L., \& Fernández-Manjón, B. (2008). Educational game design for online education. Computers in Human Behaviour, 24(6), 2530-2540.

Nitecki, E. (2015). Integrated school-family partnerships in pre-school: Building quality involvement through multidimensional relationships. School Community Journal, 25(2), 195-219.

Onur, A. Çağlar, A. \& Salman, M. (2016). Evaluation of waste paper and improvement of environmental awareness for 5 years old preschool children. 
Bulut, A. (2020). Teacher Opinions about Children's Awareness of Zero-Waste and Recycling in...

Kastamonu Journal of Education, 24(5), 2457-2468.

Oskamp, S. (1995). Resource conservation and recycling: Behaviour and policy. Journal of Social Issues, 51(4), 157-177.

Öztap, R. (2019). Investigetion of the effect of art activities made with waste material on recycling awareness of pre-school children. Dumlupinar University. (Unpublished Master's Thesis). Institute of Educational Sciences, Kütahya.

Öztürk, M. (2018). Zero waste management. Journal of Health Thought and Medical Culture. 45. $76-77$.

Patton, M. Q. (2005). Qualitative research. New York: John Wiley \& Sons, Ltd.

Poskus, M. S. (2015). Predicting recycling behaviour by including moral norms into the theory of planned behaviour. Psichologija, 52 (52), 22-32.

Pressoir, E. (2008). Preconditions for young children's learning and practice for sustainable development. Pramling- Samuellson, I. \& Kaga, Y (Eds.), The contribution of early childhood education to a sustainable society in (pp. 57-62). Paris: UNESCO.

Rahmayanti, H, Oktaviani, V. \& Syani., Y. (2019). Development of sorting waste game android based for early childhood in environmental education. Journal of Physics: Conference Series. 1434 012029. doi:10.1088/1742-6596/1434/1/012029.

Rances, J. N. (2005). Student perceptions of improving comprehension through drama as compared topeotry and fiction in college English freshman composition courses. (Unpublished doctoral dissertation), Widener University, Chester, PA.

Rivera, M. (2009). Latinos and problem solving. The hispanic outlook in higher education, $19,15$.

Salonen A. 0. \& Tast, S. (2013). Finnish early childhood educators sustainable development. Journal of Sustainable Development; 6 (2); 70-85.

Samuelsson I. P. (2011). Why we should begin early with ESD: The role of early childhood education. Department of Education, Communication and Learning, University of Gothenburg. Springer Sciences Business Media B.V. 43: 103-118.

Şenel, M. C. (2012). Design principles of power transmission mechanisms in wind turbines dynamic behaviour (Unpublished master's thesis). Ondokuz Mayıs University Institute of Science. Samsun.

Stake, R. (1995). The art of case study research. Thousand Oaks, CA: Sage.

Steward, C.J. \& Cash, W. B. (1985). Interviewing: principles and practices. Dubugue, IO: Wm. C. Brown.

TC. Environment and Urban Ministry (2017). Zero waste handbook. Ankara.

Temel, D. \& Türkoğlu, B. (2019). The effect of mother and father attitudes to social skills of kindergarten children according to the settlements. GEFAD / GUJGEF 39(2): 843-871.

Tezel Şahin, F. \& Turla, A. (2003). Examination of family participation studies in preschool education institutions. Omep 2003 world council meeting and conference book (I.379392), Ankara: Ya-Pa.

The World Bank has prepared a report on the increasing amount of waste in Sub-Saharan Africa and Asia and the devastating consequences of inadequate waste handling.(2018).Retrieved from https://tr.sputniknews.com/cevre/201809211 035314327-birlesmis-milletler-dunya-bankasi-rapor-atk-artma-asya-sahraalti- 
africa/

Toran, M. \& Özgen, Z. (2018). Family Involvement in Preschool Education: What Do Teachers Think and Do? Journal of Qualitative Research in Education, 6(3), 229-245. DOI:10.14689/issn.2148-2624.1.6c3s11m.

Türker, H. H. (2009). Investigation of the effect of 5 E learning cycle model for the concept of force on meaningful learning (Unpublished Master's Thesis). Niğde University, Institute of Social Sciences, Niğde.

Turner, H., Mayall, B., Dickinson, R., Clark, A., Hood, S., Samuels, J., \& Wiggings, M. (2004). Children engaging with drama: An evaluation of the National Theatre's drama work in primary schools. London: Institute of Education, University of London.

Uluyurt, F. (2012). Ongoing pre-school education institutions of some variables of peer relations children aged 5-6. (Unpublished Master's Thesis). Selcuk University, Konya.

United Nations Educational, Scientific and Cultural Organization (1992). Agenda 21 - Report of the United Nations Conference on environment and development. Rio de Janeiro: UNESCO.

Ünüvar, P. (2010). Comparison of parent and teacher opinions regarding family participation studies. Kastamonu Journal of Education, 18 (3), 719-730.

Usta, N., Işık, D. A., Şahan, G., Genç, S., Taş, F., Gülay, G., Diril, F., Demir, Ö. \& Küçük, K. (2017). The opinions of pre-service teachers on the usage of games in mathematics teaching. International Journal of Social Sciences and Education Research, 3(1), 328- 344.

Valle, P, Reis, E. Menezes, J. \& Rebelo, E. (2004). Behavioral determinants of household recycling participation. Environment and Behaviour, 36(4), 505- 540.

World Bank, FAO and IFAD (2015). Gender in Climate-Smart Agriculture. Module 18 of the Gender in Agriculture Sourcebook. World Bank, Washington DC.

Yaffe, S. (1989). Drama as a teaching tool. Educational leadership, 46(6), 29- 35.

Yeșilyurt. Z, C. (2011). Expectations of parents who attend kindergarten with their children from pre-school education institutions and their expectations from institutions. Pamukkale University. Social Sciences Institute. (Unpublished Master's Thesis), Denizli.

Yıldırım, A. \& Șimşek, H. (2011). Qualitative research methods in the social sciences. Ankara: Seçkin.

Yin, R. K. (2009). Case study research: Design and method (4th ed). Thousand Oaks, CA: Sage.

Yumuș, M. (2013). Research on Opinions of Preschool Teachers about Behavioural Problems of 36-72-month-old Children and Determining Coping Strategies. (Unpublished Master's Thesis). Hacettepe University, Institute of Health Sciences, Child Development Program, Ankara.

Zahle, J. (2019). Data, epistemic values, and multiple methods in case study research. Studies in History and Philosophy of Science, 78(32-39).

\section{Biographical Statement}

Ayhan BULUT has worked as a teacher in different schools of Turkey between the years 1998-2019. He has been working as an assistant professor at Bayburt University, Faculty of Education, Preschool Teaching Program since 2019. 